\title{
Abraham - The Last Supper - Cathedral. Biblical Symbols of Medieval Origin in Simion Cristea's Sculpture
}

\author{
Simion Cristea*
}

\begin{abstract}
In this article I will overview the theories on biblical symbols that laid at the basis of several personal sculptures. Such is the case of Old Testament motifs drawing on Abraham and the New Testament (the Last Supper and the Cathedral). The main sources of inspiration are external and internal frescoes of medieval monasteries from the Byzantine and neoByzantine space.
\end{abstract}

Keywords: Romanian Medieval art, biblical symbols, sculptures of religious inspiration, Byzantine spirit, transcendence

\section{Introduction}

The study of Romanian medieval art, both religious and lay has been one of my concerns ever since I was a student; during my college years I started to study the external and internal frescoes from the church walls of Bukovina. In the presentation that follows, I grouped the great biblical themes according to their appurtenance to the Old and New Testament; Cherub contains elements both from the Old and the New Testament: The Last Supper and Prayer are mostly inspired from the New Testament and The Cathedral from Romanian feudal art. I do not aim at providing a minute presentation of the themes and symbols used, simply a general one and the way of work, the materials used and how I perceived these themes and symbols.

In all the sculptures presented, the raw material of work is wood due to its warm nobility which gives a multitude of possibilities for expression. The wood essences I use most often are the following: pear, plum, cherry wood and rarely elm, oak, ash and acacia. In old times, the statues of gods were painted in powerful colours to give supplicants a true to life feeling. In ancient Greece, the deities and heroes' eyes were strongly shaped in black to increase this sensation. This device has endured in time and can be encountered in Gothic cathedrals and the saints' statues were painted in lively

\footnotetext{
* Associate Professor, PhD. George Enescu National University of Arts, e-mail: scristea@arteiasi.ro
} 
colours to increase this sensation. This procedure also endured in time as in gothic cathedrals the statues of the saints and the wood altars inside the church were also painted. I reluctantly used colour myself, especially the colour of wood enriched by patina. To increase the touch of sacrality we used gold foil applied to some parts of the sculptors. Gold has always been considered the perfect metal by almost all peoples in the world. To represent a transcendental world anonymous Byzantine artists use gold in the background of the icons they painted. This particularly inspired me to use gold in my sculptures. Apart from the images I comment, in this article I also deal with images of sculptures achieved towards time.

\section{Biblical Themes Transposed to Sculpture 2.1. Abraham}

The theme was suggested to me by a documentation visit in Bukovina. At the church of Voroneț monastery, on the western façade there is an outstanding representation of the Last Judgement. The theme is an exciting one and the mural painting truly magnificent, despite its frightening character. Somewhere in a corner the place where the righteous will go, namely Heaven, was also represented. Here there is a representation of Abraham, who holds the souls of the righteous near his chest for protection. The chest was a part of vestments which gave the possibility to the ones wearing them, to be used to transport certain goods. The vestment, along with the body wearing it, looks like a bag. By means of Adam's representation, I aimed at symbolising Heaven which is, for every Christian, the place where he would like to spend his eternal life. Since the beginning of the world, people have envisaged heaven in various ways. Most often it is depicted as a garden with spontaneous and luxurious vegetation, as a result of heavenly activity. There is spring in the centre for the purpose to create life and knowledge. Beasts live there in freedom, their language is understood by man who gives names to each and every one of them. Man's spontaneous domination is symbolised by the dominance of the intellect over the senses and instincts, as well as the knowledge of the beings' own nature. Heaven enjoys eternal spring and a day here equals a thousand years on earth.

"Study" on Abraham - In this work of small dimensions, I tackled the theme of Heaven. Since I was at the beginning of my career, the figurative character of the composition is obvious. As working technique, the present composition is a combination between relief and ronde-bosse, bi and three-dimensional. Abraham is shown as a bust and he holds the souls of the righteous near his vestment chest. Portraits are dealt with schematically because I did not intend to clearly individualise them. The surface around the main character is golden and so are the vestments and aureoles of the ones near his chest. The work ends in a curve line that brings quietude to the 
whole. The composition is supported by three little legs which ensure good stability.

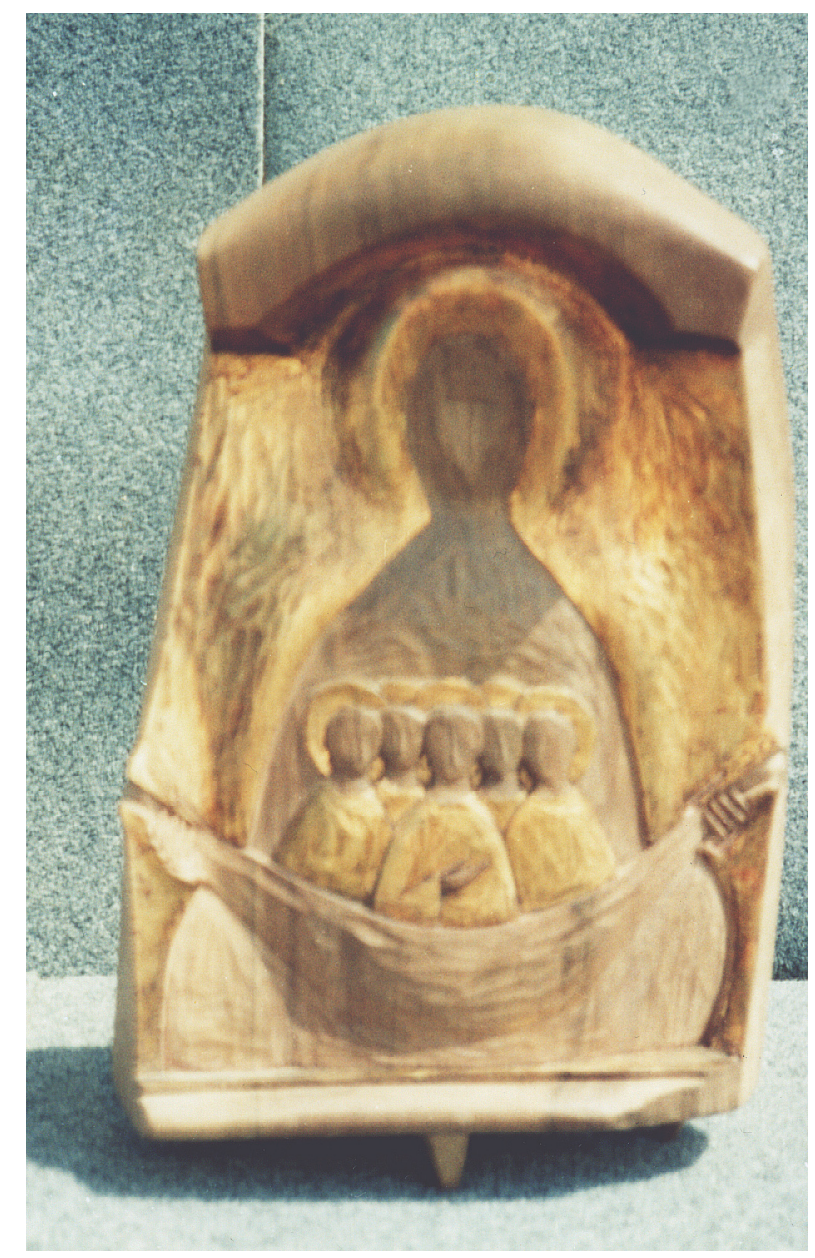

Fig. 1. Studiu (Avraam)

"Abraham I" - In this work, the figurative character of the composition can be barely perceived. Carved in pear wood, the composition is partially golden and polychromous. It is conceived from two segments following the general shape of a trapeze. In this composition I made use of the illusion that the reversed perspective offers. In the upper segment, Abraham enthrones his hands bent on the sides holding the souls of the righteous. They are suggested by fourteen portraits that depict human silhouettes in a stylised manner. The silhouettes are coloured in white, the symbol of purity, and the surface around them is golden. Here, gold is a reference to a celestial world. 
I envisaged the composition so that it can be admired standing. There is no physical relation between the two component segments, they are simply positioned near each other. Through this distance, I aimed at suggesting the place held by Abraham in heaven. The natural colour of pear wood is emphasized by the white silhouettes and the golden foil. The shape of the composition is geometrically cut and surfaces well-grinded. All these give special distinction to the composition.

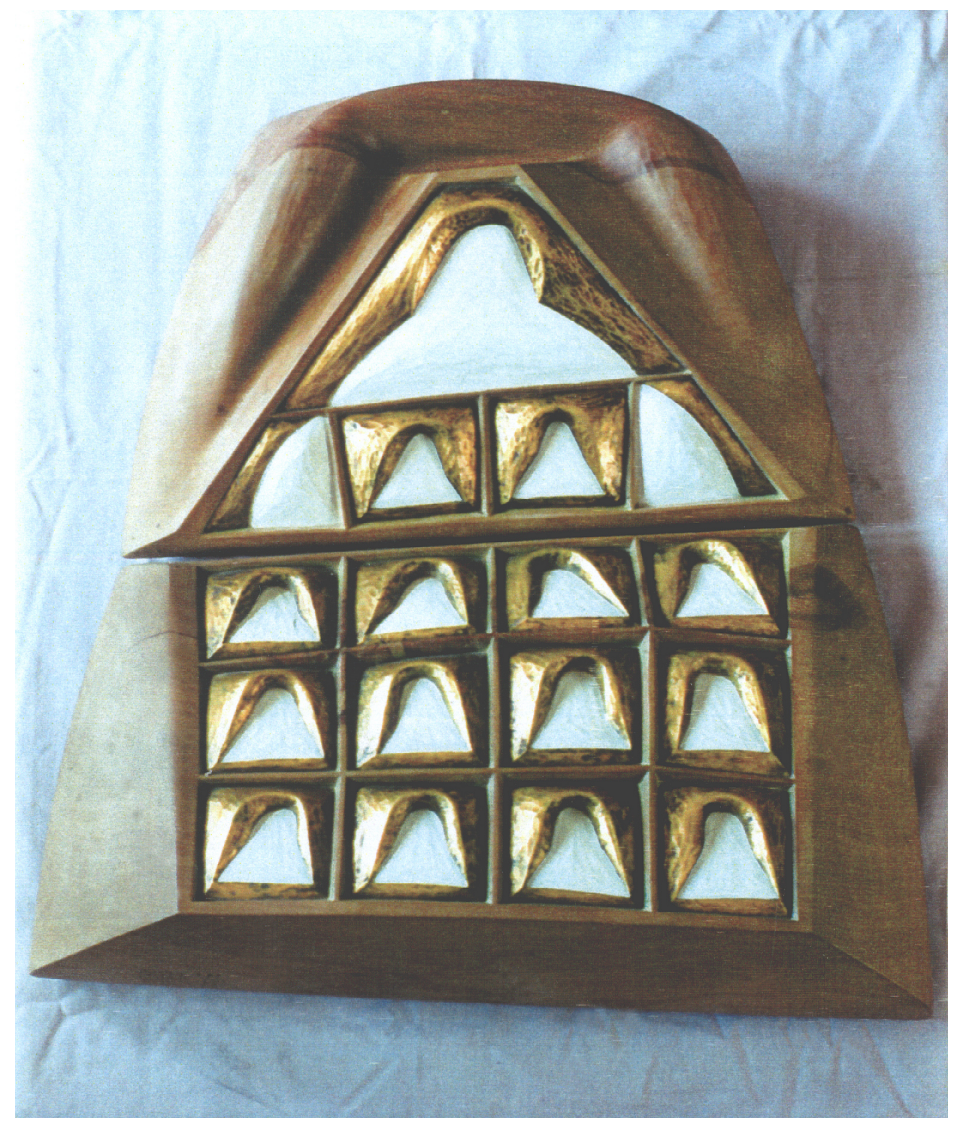

Fig. 2. Avraam I

"Abraham II" - Unlike the two variants previously presented, the current composition does not draw on Abraham's representation from the western façade of the Voroneț monastery. The character is shown entirely, standing on his two feet with a slight right bend ahead. The work was cut in simple geometrical shapes, the only "accidents" consisting in the triangle which suggested the souls of the righteous. The pear wood was used to carry out the work. The form is simple, with a discrete modeling. The register with the 
souls of the righteous is represented by a triangle which hosts twelve figured human silhouettes. Their surface is coloured in white with a golden space around them. This triangle repeats itself in the upper part of the work, as well, thus suggesting the character's head. Through the patina applied to the work, the stress falls on the pictorial character, where white and gold join the natural wood colour in great emphasis. The work can be found in the cultural heritage of the "Museum of Art and Ethnography" in Bacău and was awarded the prize of this cultural institution at Saloanele Moldovei (Moldavian Saloons) in 2001.

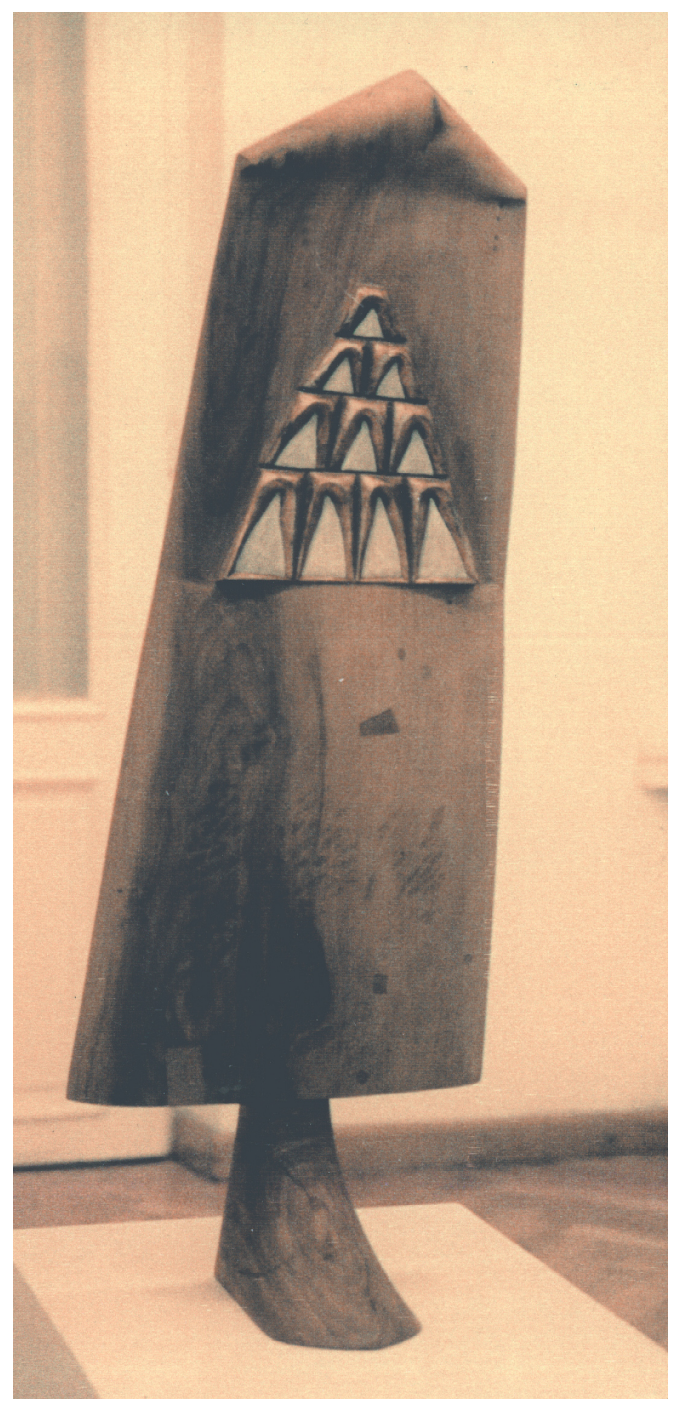

Fig. 3. Avraam II 


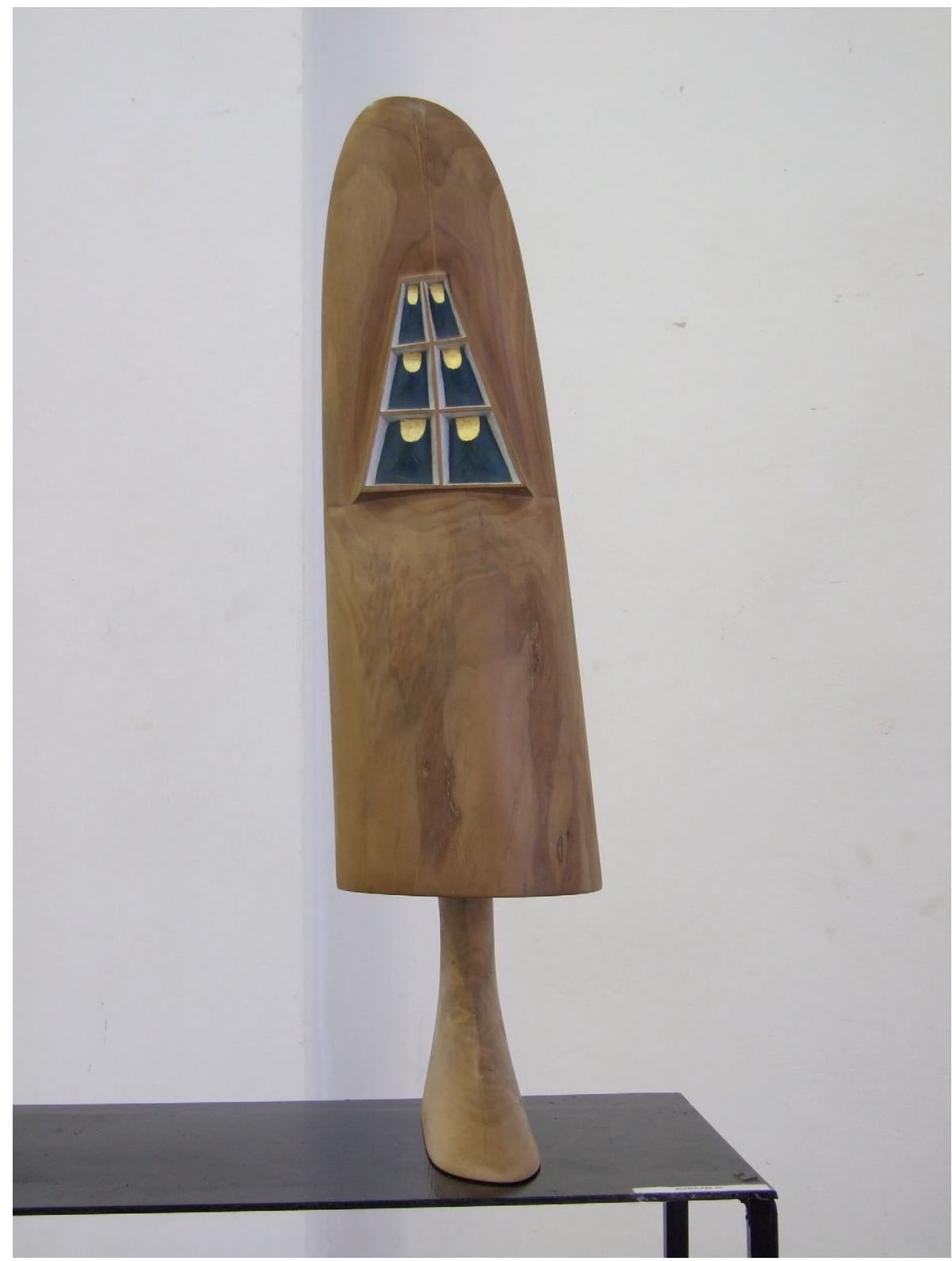

Fig. 4. Avraam III 
Abraham - The Last Supper - Cathedral. Biblical Symbols of Medieval Origin in Simion Cristea's Sculpture

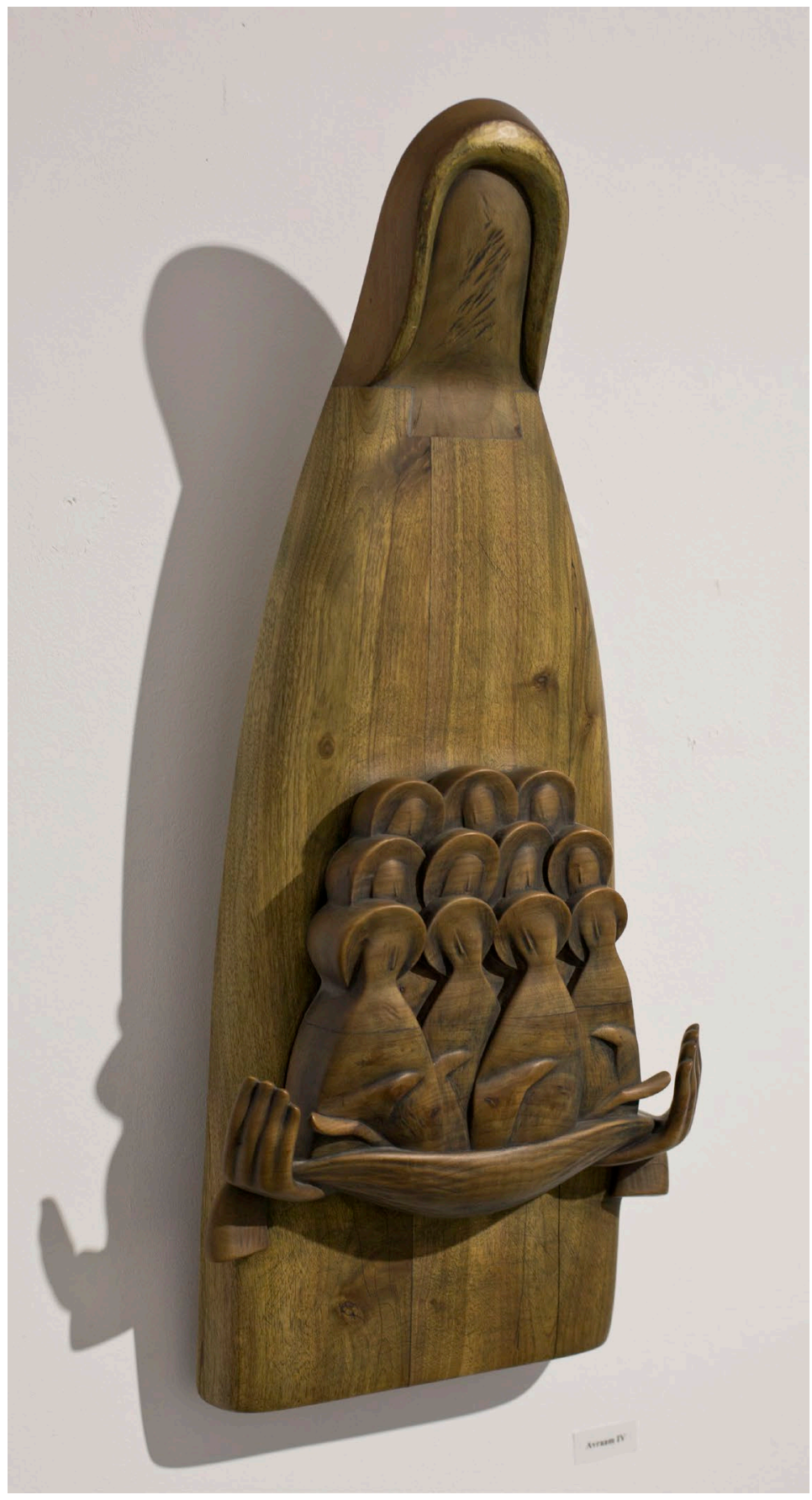

Fig. 5. Avraam IV 


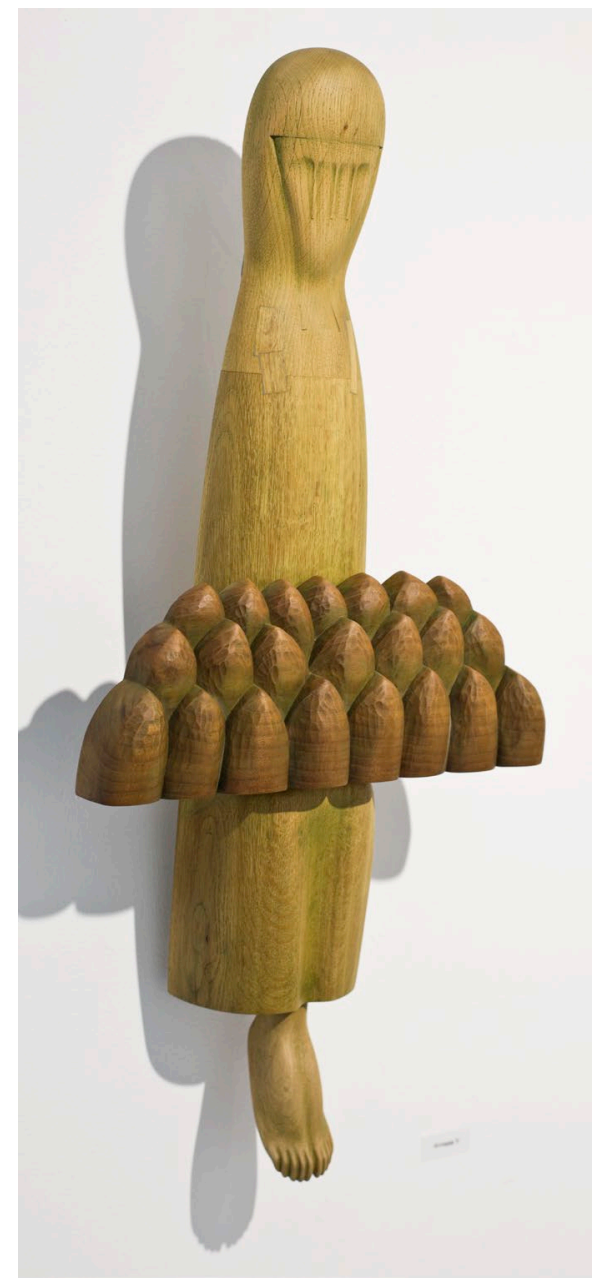

Fig. 7. Avraam VI

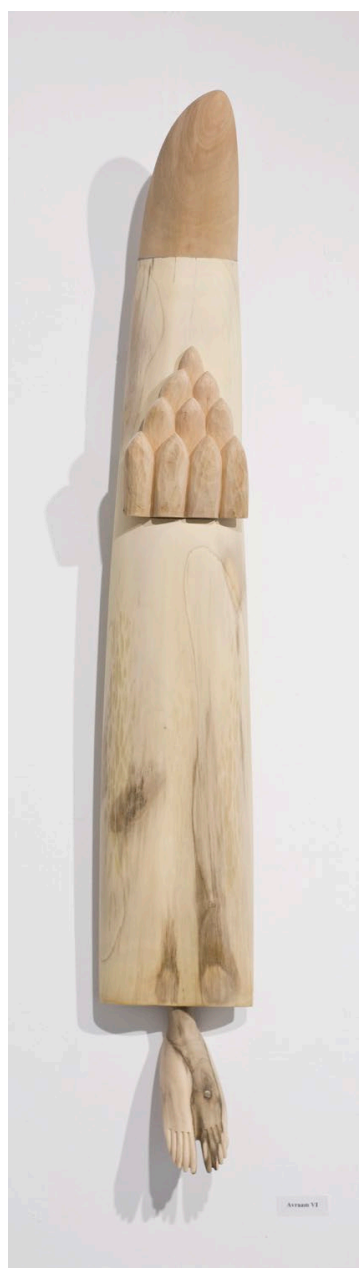

Fig. 6. Avraam V

\subsection{The Last Supper (Roadside Crucifix)}

"The Last Supper" (Roadside Crucifix) - This is a monumental work, located at the basis of the archaeological site of Cucuteni in August 2002, a work elaborated and displayed at the sculpture symposium, "Art and Sacrality" organised by Ax Art Foundation and Cucuteni Town Hall. As raw matter for the accomplishment of the work, oak wood was used, freshly brought from the forests nearby. 
Starting from the name of the Symposium itself, the touch of inspiration was a very generous one, especially drawing on the field of the sacred. For me, it was extremely convenient because in the past 20 years, especially in 1986, my source of inspiration had been "the field of the sacred", medieval church art, in general and biblical themes, in particular.

The starting point for the accomplishment of this work is "The Last Supper", both in its iconographic representation and with respect to the biblical rendering of the event. The Last Supper, as event in itself, occurred in a pavilion, at a certain height towards the land. I tried to suggest this by giving the work a grand form. To subscribe to the plastic conception of Orthodox sacral art, where the carved image and three-dimensional representation are forbidden, I made use of the stressed flattening of the central element of the work which greatly resembled an icon's means of representation. The large shape of the main element is that of a window, especially encountered in churches. We know that, at the Last Supper, Eucharist was instituted as a "window" of communication between earth and sky, between man and God. I attempted to suggest this relation though the mainly vertical development of the work since the ascension to the sky was obvious.

At the moment of the Supper, the apostles were ordinary people, they had not been sanctified yet. I suggested this profoundly human nature by means of the three beams through which four ogives ran. The fourth beam only contains a single ogive to point out to the Saviour's solitude before the excruciating passion during the Good Friday. Although he is the Son of God, He will fear what follows because of His human nature. To account for the halo of His suffering, we used half of the circle for the last beam.

The fact that I pierced the beams when building these ogives (which stand for stylisations of human silhouettes), was a matter exclusively pertaining to fine arts. The work projected on the green hill and its colour, along with the wood, emphasizes the outline. The work was envisaged for admiration from afar so I let go any useless detail. The work's plastic expressivity is given by the relation between its great shape and the only details preserved, i.e. the ogives. To preserve the austere atmosphere of the theme, the surfaces have been curved using the chisel and the ogives bear saw marks. Using few plastic means, my wish was to render the work as expressive as possible.

The work is also called "Roadside Crucifix" since its general shape recalls the roadside crucifixes carved by peasants and positioned at the crossroads. This work also stands at the crossroads of past, represented by the style of Cucuteni and the road that takes us to the contemporary world. 


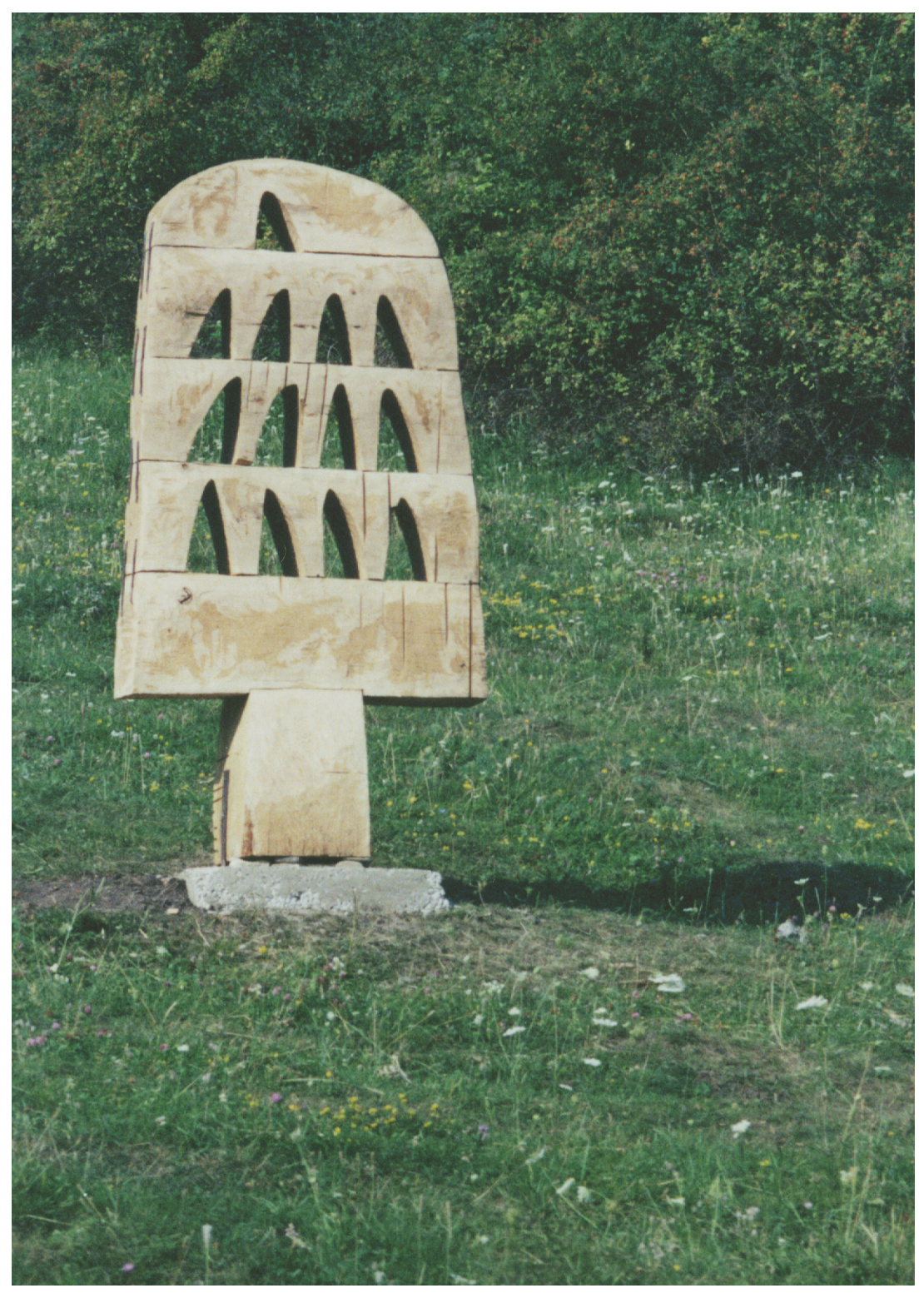

Fig. 8. Cină (Troiţă I) 


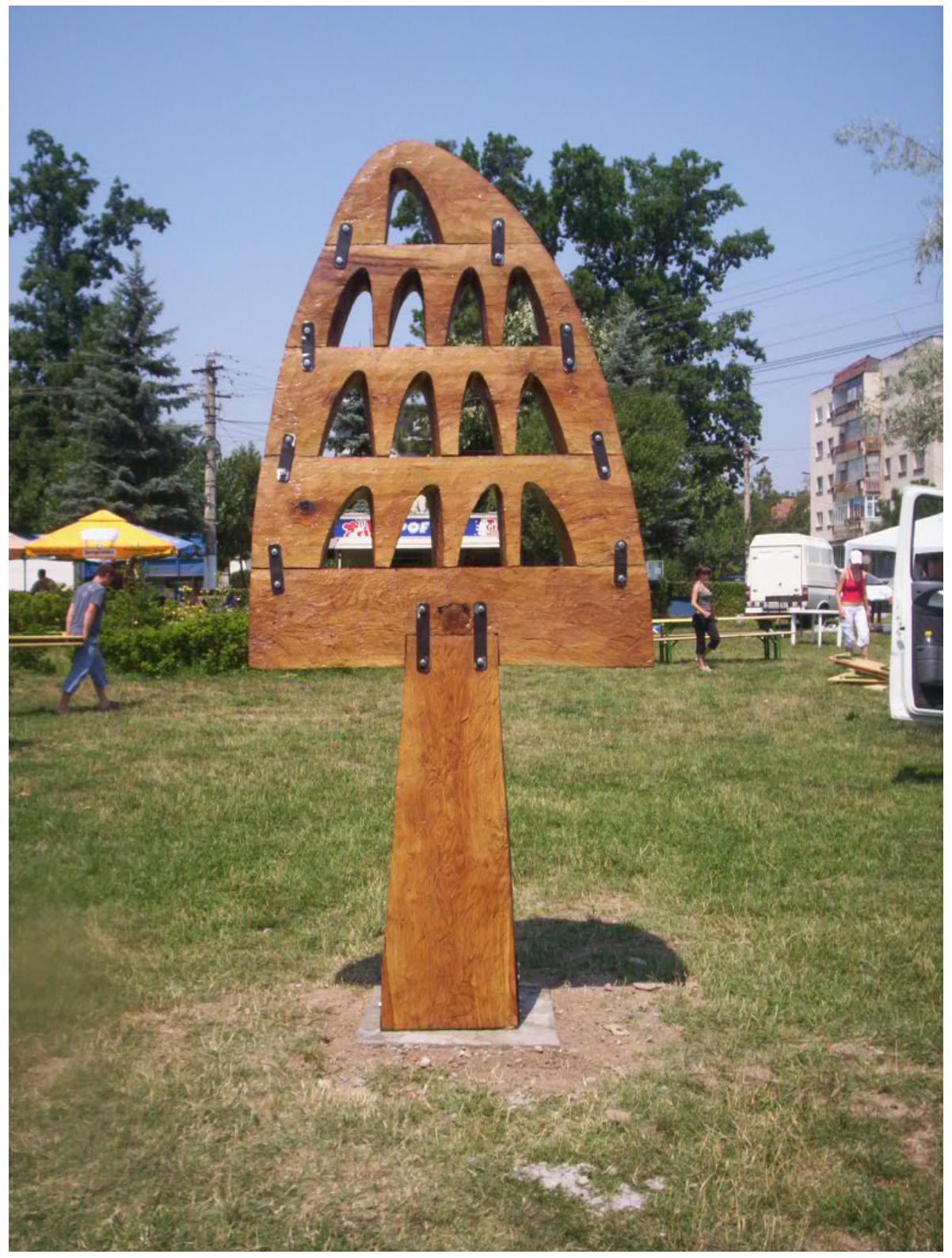

Fig. 9. Cină (Troiță II) 


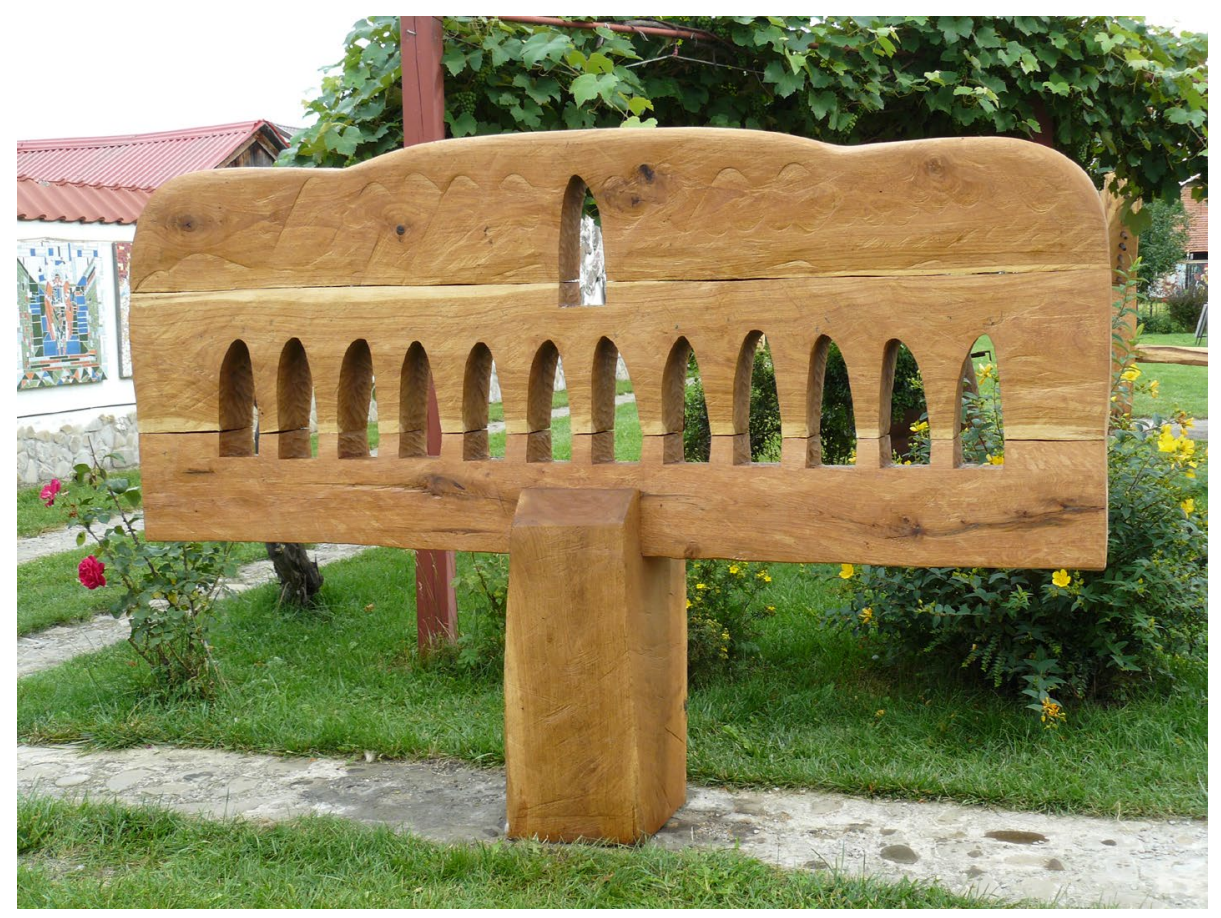

Fig. 10. Cină (Troiță III)

\subsection{The Cathedral}

This title was chosen to reflect several plastic concerns I had in the beginning of the $90 \mathrm{~s}$. We started to build on this theme from a symbol that was extremely present in all world cultures, namely the hand.

The hand is the expression of the idea of activity, power and domination. In the languages of the Far East, word partnerships such as "to lay hands" or "to let go" have the meaning of "starting and finishing an activity".

The hand is a royal mark, an instrument of rule and symbol of domination. In Hebrew, the word "hell" has two meanings, of hand and power. The king's hand is the one that does justice and the sign of the hand that does justice was the mark of French monarchy during the Middle Ages. God does justice using his left hand, whereas the right hand is reserved for mercy. The right hand is the hand that blesses as the symbol of the royal power.

The Buddhist canon presents the tight hand as a symbol of dissimulation, secret, esotericism. Buddha is never represented with his hands tight, hence the lack of secrecy regarding his teachings. In Chinese culture, the right hand corresponds to action, and the left one to reaction and wisdom. 
In the Celtic world, hand symbolism mingles with the one for the arm, the hands raised and palms stretched as gesture for begging. The hand has a magical value, as well. A king who lost an arm, the right one, respectively, cannot rule anymore because of the likely dangerous potential that a lost right arm brings. In pre-Columbian Central America, the palm with the fingers stretched and often the thumb up is frequently represented both in reliefs and ronde-bosses, in which number five is also the symbol of the fifth day.

In the Christian and biblical tradition, the hand symbolizes power and supremacy. To be on God's hands means to receive the manifestation of His Holy Spirit. The man touched by God's hand is a man who received God's power. In the Old Testament, when God's hand is brought into play, God is shown in His full power. God's hand may create, protect or smash, if necessary. The right hand blesses and the left one dooms. In Christian iconography, God's Hand is represented as coming out of the clouds to manifest its Godly character and it is surrounded by a cross-like aureole. "To be in God's hands" or "to be at the mercy of someone" means "to entirely depend on him" or "to be crushed by him, when required".

During the ordainment service, the one to be ordained lays his hands on the bishop's. The sense of the gesture takes on Christ's last words: "Father, into your hands I commit my Spirit". By "laying one's hands" on someone, energy or power is transferred. When priests are ordained, the bishop lays hands on the head of the ordained to be and through prayer, the former makes the passage of the divine grace easier on the latter.

The hand is an exclusively human synthesis between masculine and feminine as it serves as weapon and tool and can be extended via instruments. Also, when it shows a conquest or claims power - the hand that does justice, laying on an object or territory, given on the occasion of matrimony - brings distinction to the represented one in the exercise of his function and in a new situation.

Cathedral I and Cathedral II are two works which illustrate a function and attitude of the hand, namely the one which blesses. In the achievement of these compositions, we started from the sacerdotal gesture of blessing and its representation in Romanian medieval iconography. The fingers' position during the blessing is Christ's monogram as graphic form.

Dionysios of Fourna in his Hermeneia of Byzantine painting (2000, pp. 228-229) argues that "when you depict the blessing hand, do not do it with the three fingers together, only join the thick finger (thumb) with the ring finger in the middle because the index one and the bent middle finger make Jesus's name. This is because the finger that rightfully stands shows the I and the bent one near him the $\mathrm{C}(=\mathrm{S})$. And the thumb and ring finger in the middle encounter and join each other, whereas the bent little finger near them marks Christ's name for the joining of the thumb with the index, the one in the middle, to show the $\mathrm{X}(=\mathrm{H})$ letter, and the little bent finger envisages 
(letter) $\mathrm{C}(=\mathrm{S})$, letters that make up $\mathrm{XC}$, that is Christ. Thus, in this manner the Builder created the human palm's fingers, as many as necessary to show his (short) name".

The title of the work comes from the resemblance between the form of the hand, in the gesture of blessing and especially prayer and ogives, the rib vaults used in the Middle Ages to build great Gothic cathedrals.

In Cathedral I the large form of the work is less elaborated and more primitive since, in the research stage, I mainly used images from various manuscripts of the Roman period. The composition is a triangle and full spaces are preferred to empty ones. The material used is pear wood which enabled us to carve the hand proper, lying on a pyramid trunk, incorporated into the composition and made of white cedar wood. This type of wood symbolizes the tree of life, hence our wish to imprint a perennial sense to the gesture represented in the work.

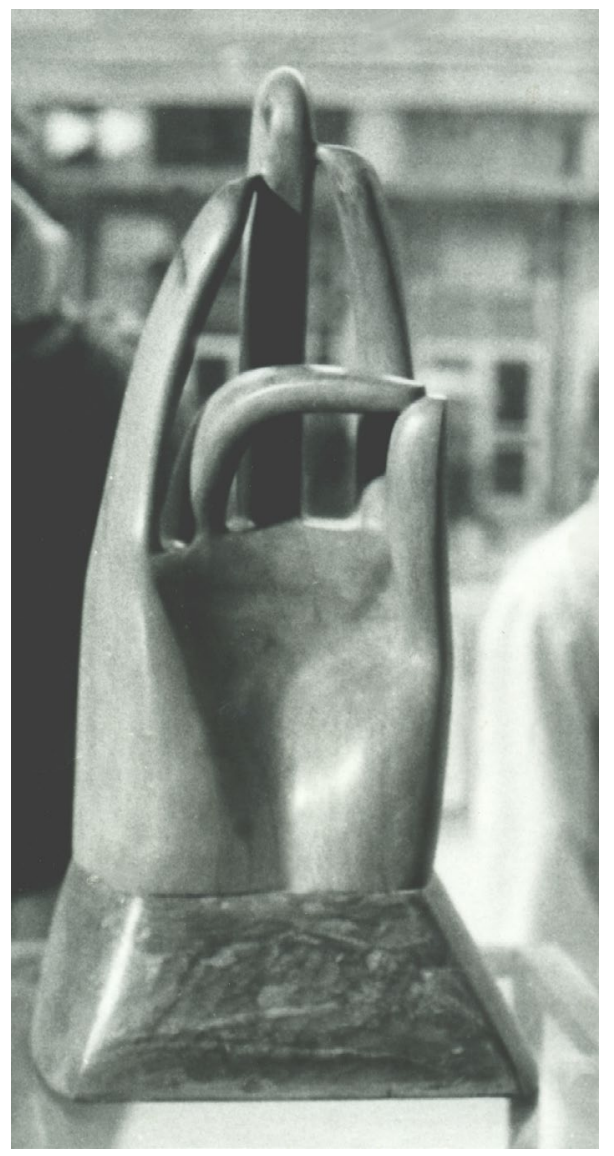

Fig. 11. Catedrală I 
In Cathedral II the form is refined and the triangle is heightened along the diminution of its basis. In the economy of the work, the empty spaces gain ground and go along better with the full ones. This composition is also carved in pear wood. The delicate volumes of the fingers are harmonised with the great volume of the palm. The austerity in the composition is highlighted by the simplicity of volumetric treatment of details and the ensemble. We preserved the wood's natural colour without any alterations from an artificial patina.

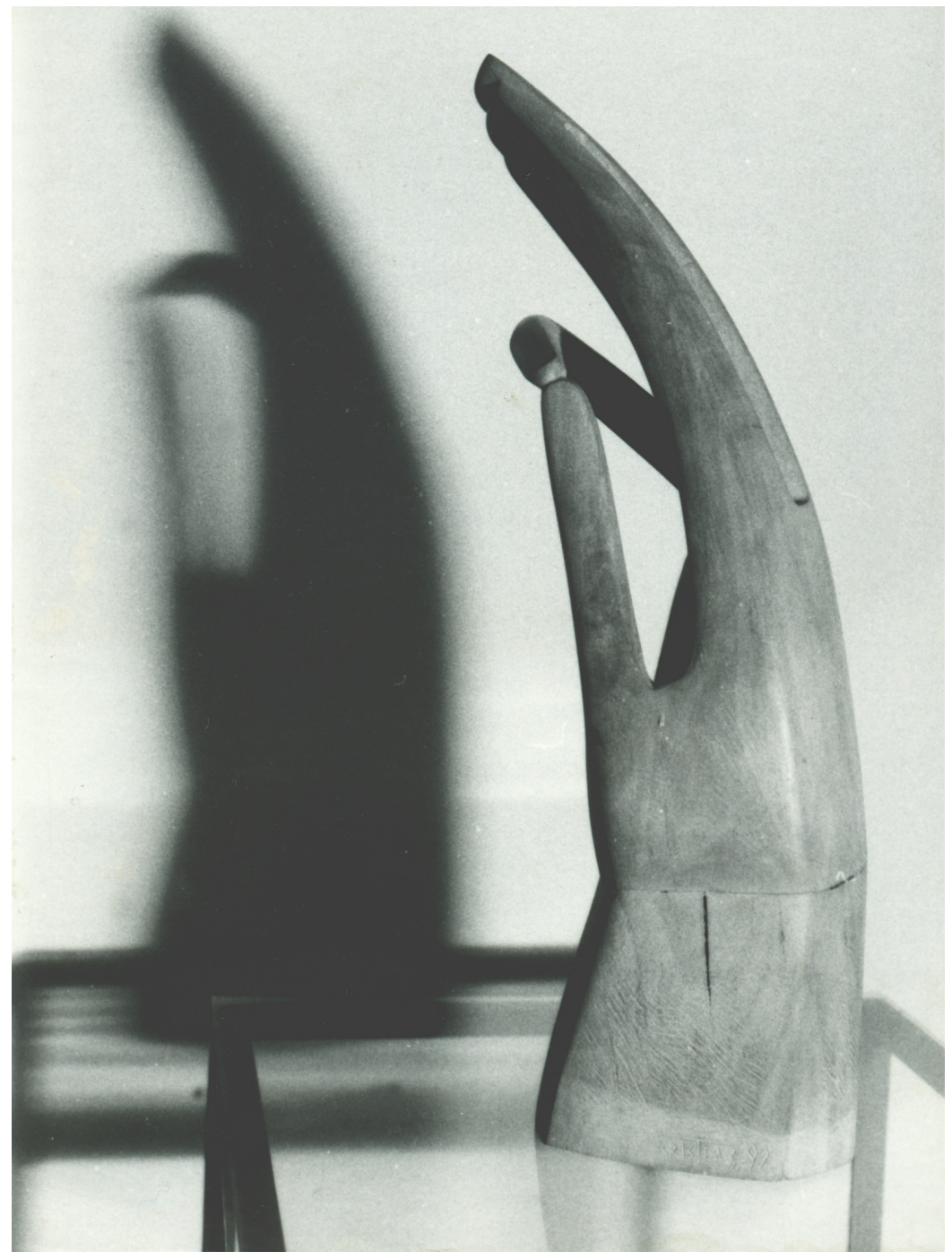

Fig. 12. Catedrală II 


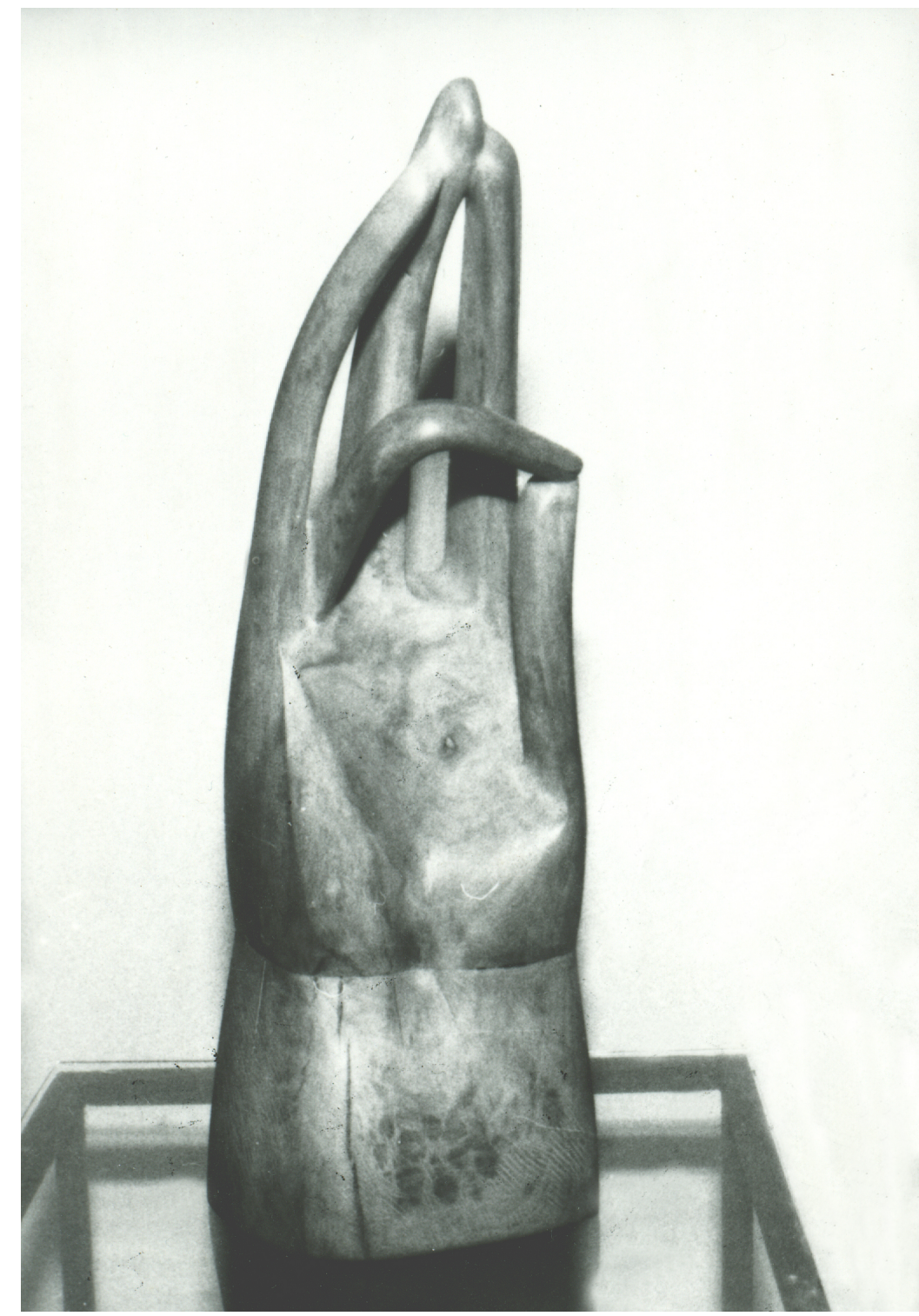

Fig. 13. Catedrală II

In this theme of the cathedral we introduced a work entitled Reliquary Hand. Worked in partially golden plum wood, it got inspiration from the jewellery boxes popular in the Western world during the Middle Ages in which the relics of a saint were preserved. 
Abraham - The Last Supper - Cathedral. Biblical Symbols of Medieval Origin in Simion Cristea's Sculpture

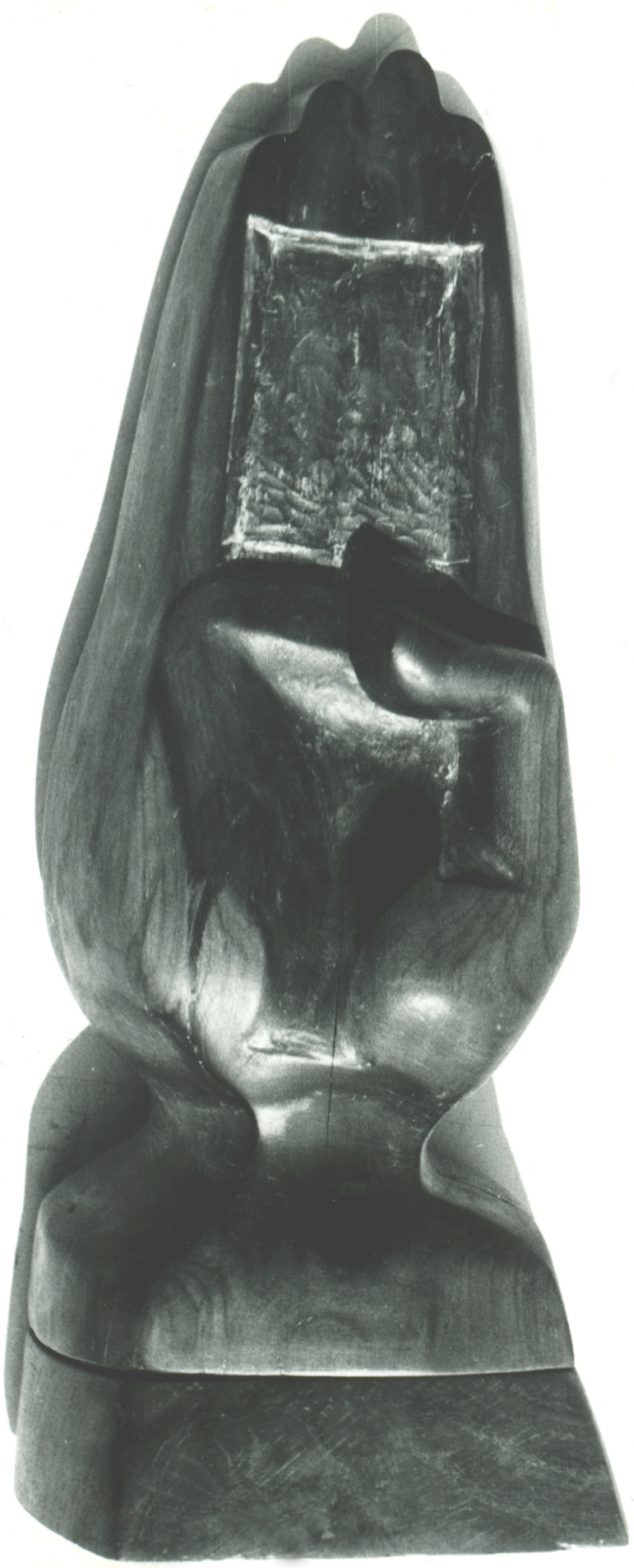

Fig. 14. Mână relicvar 


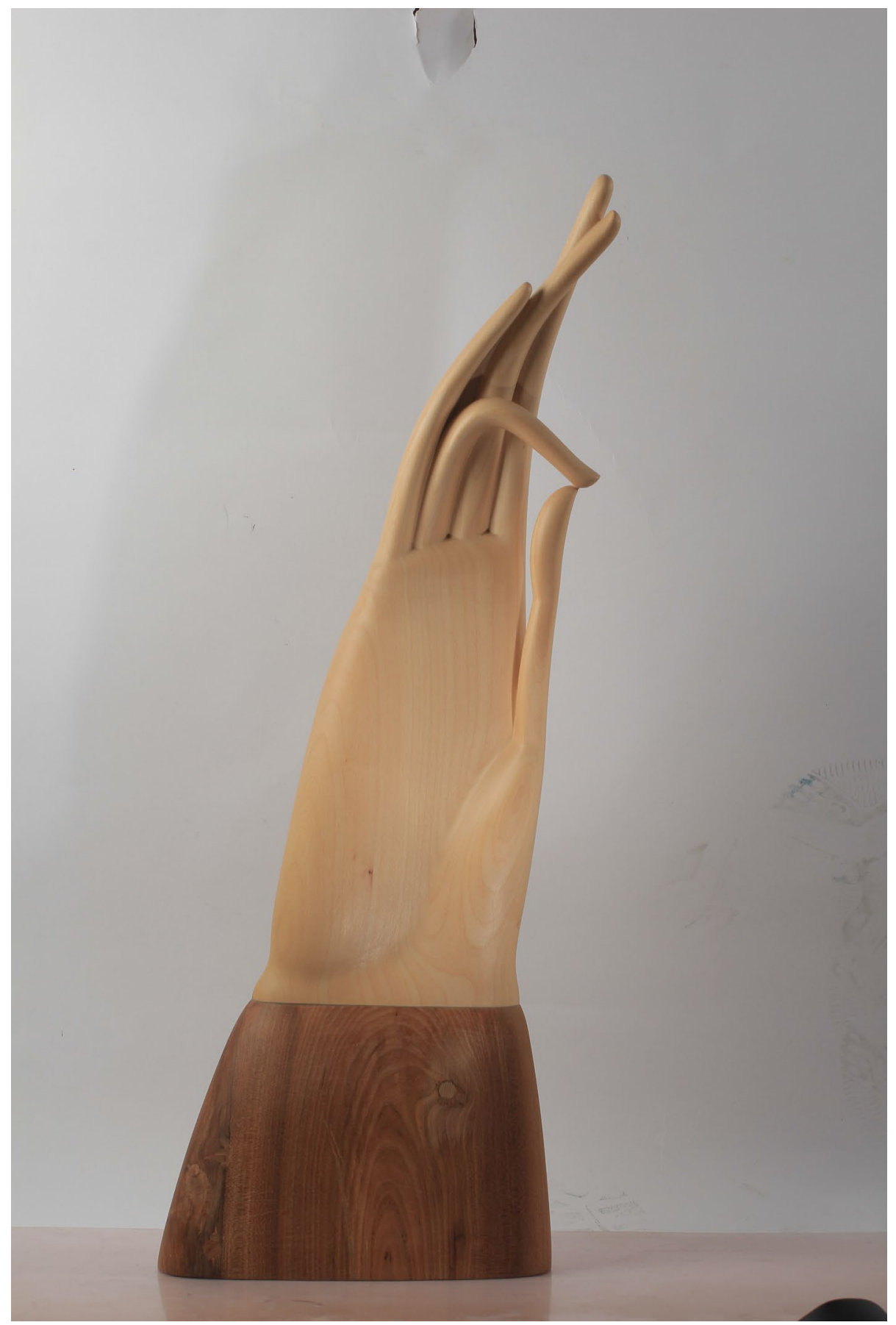

Fig. 14. Bunul Semn 


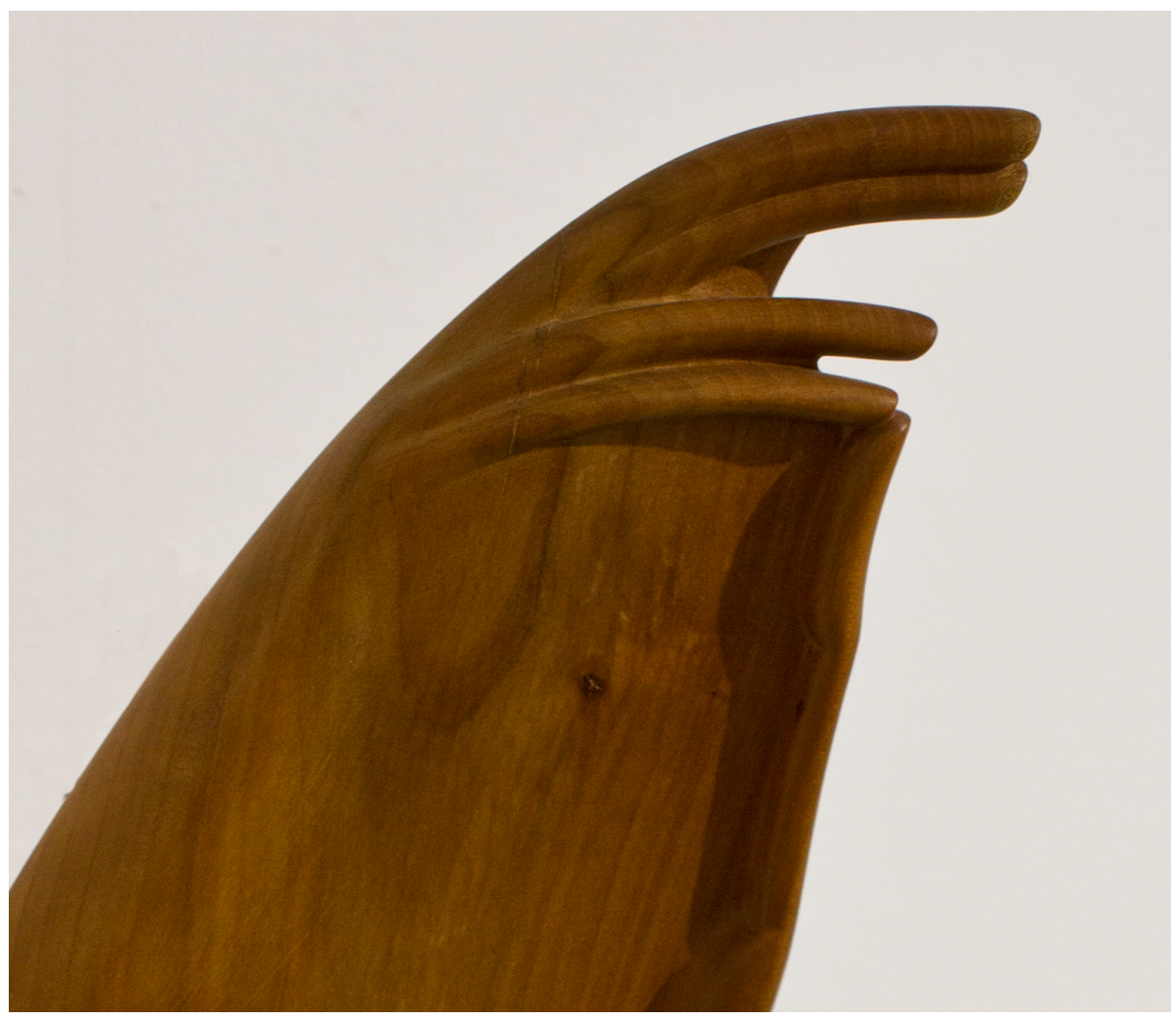

Fig. 15. Catedrala Roșie

\section{Conclusions}

In this article on my sculptural creation, I presented three themes (Abraham, The Last Supper and the Cathedral) and the symbols of heaven, bread and wine, of the hand; some of them pertain to the Old Testament (Abraham), others to the New Testament (The Great Supper, the Cathedral), some are drawing on Romanian Medieval Art (the Cathedral). In the future I intend to extend the theoretical comment to other biblical themes present in my sculptures such as the arch, the tree or the cherubim.

Translated by Ana - Magdalena Petraru, PhD 


\section{List and source of illustrations:}

Fig. 1. Studiu (Avraam)

Fig. 2. Avraam I

Fig. 3. Avraam II

Fig. 4. Avraam III

Fig. 5. Avraam IV

Fig. 6. Avraam V

Fig. 7. Avraam VI

Fig. 8. Cină (Troiță I)

Fig. 9. Cină (Troiță II)

Fig. 10. Cină (Troiță III)

Fig. 11. Catedrală I

Fig. 12. Catedrală II

Fig. 13. Catedrală II

Fig. 14. Bunul Semn

Fig. 15. Catedrala Roșie 